\title{
Temporal changes of meadow and peatbog vegetation in the landscape of a small-scale river valley in Central Roztocze
}

\author{
Bożenna Czarnecka*, Magdalena Franczak \\ Department of Ecology, Faculty of Biology and Biotechnology, Maria Curie-Skłodowska University, Akademicka 19, 20-033 Lublin, Poland
}

\begin{abstract}
The Szum is a right-side tributary of the Tanew River crossing the southern escarpment zone of the Central Roztocze region (SE Poland). Downstream of the strict river break in a section between the 10th and 12th $\mathrm{km}$ of the river course in the Szum valley, meadow and peatbog complexes have developed, associated with semi-hydrogenic and marshy soils. In an area of approx. 13 ha of the most valuable non-forest habitats, a variety of plant communities have been identified, including habitats of the Natura 2000 network and habitats that are protected under the Regulation of the Minister of the Environment (2001). These are, for instance, meadow associations Lysimachio vulgaris-Filipenduletum, Lythro-Filipenduletum, Filipendulo ulmariae-Menthetum longifoliae, Angelico-Cirsietum oleracei, and Cirsietum rivularis. The moss-sedge and sphagnum bog communities comprise noteworthy associations Caricetum limosae, Rhynchosporetum albae, Caricetum lasiocarpae, Caricetum paniceo-lepidocarpae, Caricetum davallianae, and Sphagnetum magellanici. These communities are composed of ca. 160 vascular plant species and 40 moss and liverwort species.

In 1999-2014, the greatest changes occurred within macroforb meadows, i.e. small Angelico-Cirsietum oleracei and Cirsietum rivularis patches have been transformed into Lysimachio vulgaris-Filipenduletum, while some patches of the latter association have been transformed into a Caricetum acutiformis rush. Several patches of bog-spring associations Caricetum paniceo-lepidocarpae and Carici canescentis-Agrostietum caninae have been irretrievably destroyed. Sphagnetum magellanici appears to be the least stable community among the preserved peatbogs. The changes of meadow and peatbog vegetation observed for the last 15 years are a consequence of natural processes that take place in the river valley and to a large extent human activity connected with the so-called small-scale water retention as well as the presence of a beaver colony in the area and later the abandonment of this area by beavers. Despite the multidirectional changes, the peatbogs of the Szum valley have retained their high species and phytocoenotic diversity, which indicates a substantial degree of naturalness.
\end{abstract}

Keywords: hydrogenic habitat; non-forest vegetation; species diversity; phytocoenotic diversity

\section{Introduction}

River valleys represent hydrogenic habitats characterized by a very large mosaic of abiotic conditions and, consequently, a considerable diversity of plant cover. They perform the function of natural ecological corridors, which are one of the most important routes of energy and matter flow, migration of organisms, and a link between scattered areas of great natural value $[1,2]$.

The richness of the flora and vegetation of the river valley is influenced by the intensity of ongoing fluvial processes, the physico-chemical properties of the water carried by the river, and the geological structure and features of terrain. All these factors determine the soil cover and its properties, simultaneously determining the character of the vegetation

* Corresponding author. Email: bozenna.czarnecka@poczta.umcs.lublin.pl Handling Editor: Elżbieta Weryszko-Chmielewska cover [3-6]. Special natural values are characteristic of small unregulated watercourses where human impact on the natural water cycle and economic management of the catchment (mowing, grazing, deforestation, peat excavation) has been largely limited. The plant cover of such sites is characterized by a high degree of naturalness; the considerable heterogeneity of the habitat conditions in a small spatial scale contributes to the emergence of valuable phytocomplexes, among which numerous rare and protected species can also be encountered [7-10].

The habitats of small-scale river valleys are most sensitive to fluctuations in groundwater levels. All modes of artificial regulation of the water relations, most frequently involving land drainage and the construction of small hydraulic structures, reduce local water retention and accelerate water runoff, which in turn initiates gradual changes in the soil environment and next in plant communities and their constituent species populations [11-13]. The high dynamics of moisture conditions in small river valleys, usually in the 
form of local flooding and waterlogging, is currently the most prevalent effect of the presence of a population of the European beaver (Castor fiber) [14-16].

The aim of the study was to analyze the changes taking place over a period of 15 years in the vegetation cover (floristic and phytosociological richness) represented by meadow and peatbog communities in a section of a small watercourse valley. The authors attempted to show the major directions of the changes and their determinant factors, with special emphasis on the unstable hydrological conditions prevailing in the area at the time of the analyses. Special attention was paid to determine the dynamic tendencies of species that are under strict protection and/or endangered.

\section{Material and methods}

The research was carried out in the Szum River valley in the Central Roztocze region. The river is the last right-side tributary of the upper Tanew, draining the south-western part of the mesoregion. The Szum River is a 24-km-long stream with a ca. $84-\mathrm{km}^{2}$ catchment area and flows ranging from 401 to $615 \mathrm{dm}^{3} \mathrm{~s}^{-1}$. The valley is characterized by high phytocoenotic and floristic diversity, which is an effect of the mosaic structure of habitats, i.e. the occurrence of semihydrogenic (bogged) soils and hydrogenic (marshy, mainly muddy and peatbog) soils as well as a nearly nine-fold variability of the surface and groundwater mineralization level $[7,17]$. In total, 48 types of plant communities belonging to different phytosociological classes were identified along the 4-km-long section of the river [8]. Most of them (26) are non-forest communities, a majority of which belong to wet meadows of the class Molinio-Arrhenatheretea, transitional peatbogs of the class Scheuchzerio-Caricetea nigrae, and raised peatbogs of the class Oxycocco-Sphagnetea [5]. The vascular plant flora of the area comprises 378 species representing 72 families [8].

The field research was conducted downstream of the strict river break where meadow and peatbog complexes had developed (Fig. 1a). The temporal changes of the meadow and peatbog vegetation were analyzed on the basis of 20 phytosociological relevés taken in the same patches in 1999, 2009, and 2014; all the relevés were used for floristic and phytosociological characteristics of non-forest vegetation of the study section of the river valley. Detailed analyses were carried out on 6 relevés representing meadow vegetation and 8 relevés with peatbog vegetation - 14 relevés altogether, further called patches (Fig. 1b), all of them remaining in less advanced succession of the shrub layer ( $\leq 30 \%)$. An eleven-grade species cover scale (“+” for a species with cover less than $5 \%$, " 1 ” for cover $5-10 \%$, “ 2 ” for $11-20 \%, \ldots$, " 10 " - 91-100\%) was used. The syntaxonomic affiliation of the plant communities was verified comparing it with the initial data (1999). During the successive study periods, species richness of the vascular plants was assessed for each patch. The Shannon-Wiener's index was used to evaluate the diversity of the plant communities. Species similarity between the observation periods was calculated using the Jaccard index [18].

All species recorded in the meadow and peatbog patches were classified into the main phytosociological classes: Phragmitetea, Molinio-Arrhenatheretea, Scheuchzerio-Caricetea nigrae, Oxycocco-Sphagnetea, Nardo-Callunetea, and Alnetea glutinosae. Accompanying species and species characteristic for other classes were defined as "others". The nomenclature of vascular flora follows Mirek et al. [19], bryophytes Ochyra et al. [20], and the classification of plant communities follows Brzeg and Wojterska [21] and Matuszkiewicz [22]. a

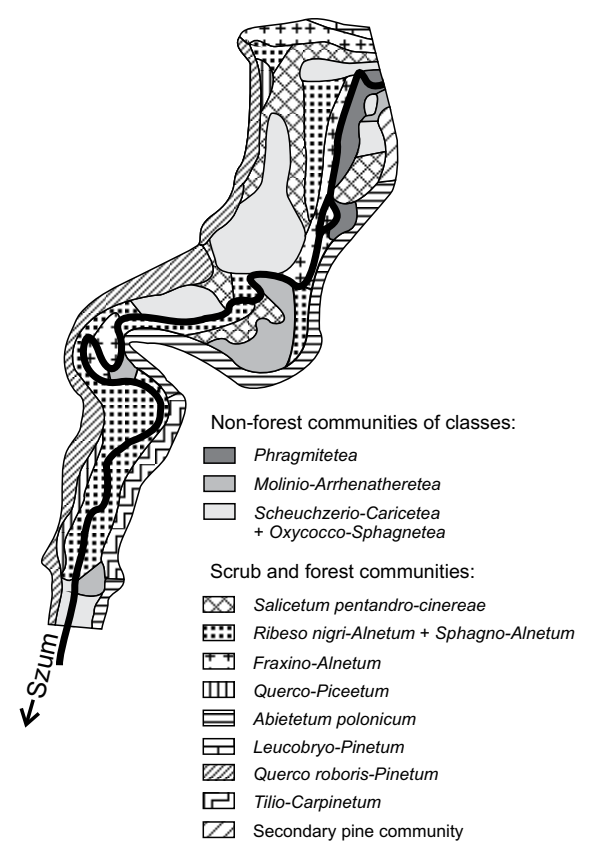

b

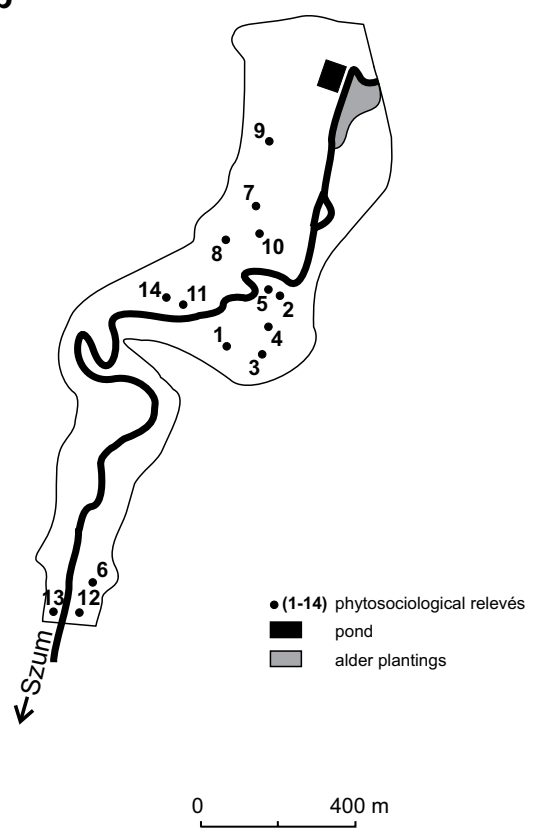

Fig. 1 Study area in the Szum River valley: spatial distribution of main groups of plant communities (in 1999; a); location of phytosociological relevés subjected to detailed analysis (numbers 1-14) in non-forest complexes of vegetation (b). 
Protected species [23] and species that are endangered in the Lublin Province [24] and Poland [25] were indicated. Additionally, protected habitats [26] and Natura 2000 habitats were noted $[27,28]$.

\section{Results}

\section{Species richness and phytocoenotic diversity}

Numerous non-forest communities have evolved in the section between the 10th and 12th $\mathrm{km}$ of the river course below the strict Szum River break. Their total surface area is approx. 13 ha (Fig. 1a); however, the varied trophy ranging from oligo- to eutrophic habitats promotes high floristic diversity. Within the meadow and peatbog complex, only ca. 160 vascular plant species and 40 moss and liverwort species were recorded. It is noteworthy that the small area comprises a substantial number of species that are under strict protection (“*”) and/or endangered in the Lublin Province/Poland (in the parentheses - threat categories): Carex davalliana Sm.* (VU/VU), C. limosa L.* (VU/VU), Dactylorhiza fuchsii (Druce) Soó (CR/-), D. maculata (L.) Soó $^{*}$ (VU/VU), Drosera anglica Huds. ${ }^{*}$ (EN/EN), D. intermedia Hayne* (EN/EN), Rhynchospora alba (L.) Vahl* (VU/ VU), Scheuchzeria palustris L.* (EN/VU), Utricularia minor L.* (EN/VU), and others. Calciphilic species that are rare in the Roztocze region such as Limprichtia revolvens (Sw. ex anon.) Loeske in Nitardy, Warnstorfia fluitans (Hedw.) Loeske in Nitardy, Campylium stellatum (Hedw.) Lange \& C.E.O. Jensen, and Scorpidium scorpioides (Hedw.) Limpr. are present in the rich moss layer. The latter species is under strict protection, likewise several Sphagnum spp.

The analyzed area is also characterized by considerable phytocoenotic diversity. A number of plant communities comprising habitats of the Natura 2000 network and legally protected habitats were identified in the most valuable non-forest habitats near Górecko Kościelne. The meadow associations include ${ }^{*}$ - protected natural habitats; in parentheses - Physis code): Lysimachio vulgaris-Filipenduletum, Lythro-Filipenduletum, Filipendulo ulmariae-Menthetum longifoliae, Angelico-Cirsietum oleracei ${ }^{\star}$, and Cirsietum rivularis $^{\star}$ (the latter two - code 37.21).

Among the moss-sedge and sphagnum bog communities, associations from the group of alkaline peatbogs (Natura code: 7230-2) and spring and percolating mires (7230-3) are noteworthy. The representative species frequently reported from these habitats include C. davalliana, C. lepidocarpa Tausch, C. panicea L., Menyanthes trifoliata L., Epipactis palustris (L.) Crantz, and Sphagnum warnstorfii Russow, and sporadically C. flava L., Eriophorum latifolium, S. teres (Schimp.) Ångstr., and C. stellatum. Small patches of associations Caricetum davallianae $e^{\star}$ and Caricetum paniceolepidocarpae ${ }^{\star}$ (54.22) were identified. A substantially larger area is covered by the community Caricetum lasiocarpae ${ }^{\star}$, whereas the acidic sedge bog-spring Menyantho trifoliataeSphagnetum teretis has developed only to a slight extent (code for both communities - 54.23). In the analyzed section of the Szum valley, there are also small patches of communities from another category, i.e. lowland raised bogs (Natura code - 7110-1), including hummock raised bogs Sphagnetum magellanici ${ }^{\star}$ and transitional and hollow peatbogs (51.2): Caricetum limosae $e^{\star}$ and Rhynchosporetum albae*. The dominant representative species on the hummocks include Oxycoccus palustris Pers., Andromeda polifolia L., Drosera rotundifolia L., and Polytrichum strictum Menzies ex Brid., whereas the hollows are dominated by R. alba, Sphagnum cuspidatum Ehrh. ex Hoffm., and C. limosa accompanied by Scheuchzeria palustris, D. anglica, and other species.

\section{Temporal changes in species diversity}

The analyzed patches of wet and fresh meadows in the Szum River valley are characterized by very high species diversity (Tab. 1). Depending on the patch and study period, the number of vascular plant species ranged from 17 to 37 . The highest frequency of taxa was reported for macroforb species: Filipendula ulmaria (L.) Maxim., Lysimachia vulgaris L., Lythrum salicaria L., Cirsium oleraceum (L.) Scop., C. rivulare (Jacq.) All., and Mentha longifolia (L.) L. The most substantial changes in species richness were noted in patches $3-5$, but a similar trend was reported for patches 4 and 5

Tab. 1 Changes in species richness and diversity of selected meadow communities in the Szum River valley.

\begin{tabular}{|c|c|c|c|c|c|c|c|c|c|}
\hline \multirow[b]{2}{*}{ Patch No. } & \multirow{2}{*}{$\begin{array}{c}\text { Relevé } \\
\text { area }\left(\mathbf{m}^{2}\right)\end{array}$} & \multicolumn{2}{|c|}{ Community } & \multicolumn{3}{|c|}{ No. of vascular plants } & \multicolumn{3}{|c|}{ Shannon-Wiener index } \\
\hline & & 1999 & 2014 & 1999 & 2009 & 2014 & 1999 & 2009 & 2014 \\
\hline 1. & 150 & $\begin{array}{l}\text { Lythro-Filipenduletum } \\
\text { ulmariae Hadač et al. } 1997\end{array}$ & $\begin{array}{l}\text { Lythro-Filipenduletum } \\
\text { ulmariae Hadač et al. } 1997\end{array}$ & 17 & 20 & 25 & 1.14 & 1.19 & 1.27 \\
\hline 2. & 150 & Filipendulo ulmariae- & Filipendulo ulmariae- & 22 & 18 & 19 & 1.22 & 1.07 & 1.12 \\
\hline 3. & 150 & $\begin{array}{l}\text { Menthetum longifoliae } \\
\text { Zlinska } 1989\end{array}$ & $\begin{array}{l}\text { Menthetum longifoliae } \\
\text { Zlinska } 1989\end{array}$ & 17 & 31 & 30 & 1.10 & 1.36 & 1.32 \\
\hline 4. & 150 & $\begin{array}{l}\text { Cirsietum rivularis } \\
\text { Nowiński } 1927\end{array}$ & $\begin{array}{l}\text { Lysimachio vulgaris- } \\
\text { Filipenduletum Bal.-Tul. } \\
1978\end{array}$ & 37 & 27 & 22 & 1.42 & 1.35 & 1.22 \\
\hline 5. & 150 & & Caricetum acutiformis & 30 & 20 & 19 & 1.34 & 1.08 & 1.09 \\
\hline 6. & 150 & $\begin{array}{l}\text { Lysimachio vulgaris- } \\
\text { Filipenduletum Bal.-Tul. } \\
1978\end{array}$ & $\begin{array}{l}\text { Sauer } 1937 \\
\text { Lysimachio vulgaris- } \\
\text { Filipenduletum Bal.-Tul. } \\
1978\end{array}$ & 27 & 26 & 24 & 1.28 & 1.27 & 1.21 \\
\hline
\end{tabular}


where a significant decline in the number of taxa, by 27 and $33 \%$ respectively, was found in 2009. During 5 successive years, a visible decrease in species number was observed only in patch 4 . In two out of 6 patches analyzed, namely in patches 1 and 3, an increase of species richness was noted. The greatest changes took place in patch 3 where the species number increased by $80 \%$ between the first and the second study period. The Shannon-Wiener index showed values of 1.10 (1999) and 1.36 (2009).

Despite the significant changes in some of the analyzed meadow communities in 1999-2009, the total number of species in all 6 study patches remained at a similar level (59 and 57) and a downward trend was only observed during the recent 5 years (Fig. 2a).

In general, also in the case of the species composition of the mire communities studied, greater changes were observed during the longer period (10-15 years) than in the 5-year period. Different trends reflected by the Shannon-Wiener

a
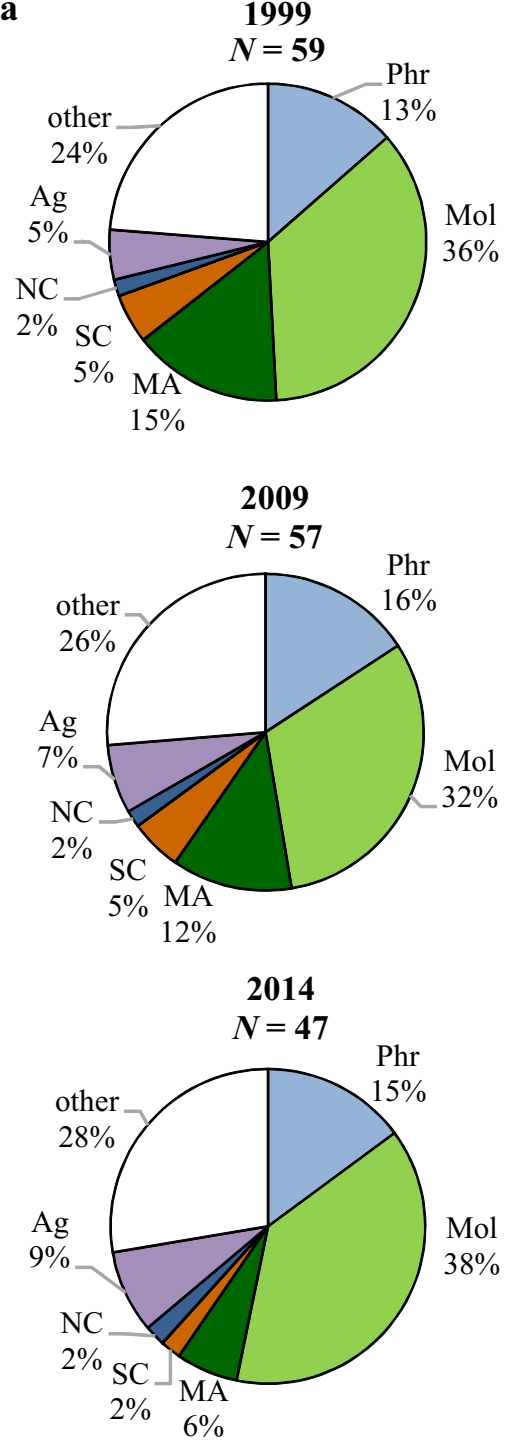

index were observed in the individual peatbog patches (Tab. 2). In patches 7,8 , and 10 , there was an increase in the species richness of vascular plants accompanied by an increase in the value of the diversity index usually caused by the presence of sporadic taxa. The greatest stability in species number was found in a small patch (No. 12) of the Caricetum davallianae association. For all the study periods, the total number of taxa was very similar, ranging between 85-89 (Fig. 2b).

\section{Temporal changes in community composition}

In all the patches, greater changes in the species composition took place over the first 10 years (1999-2009), compared with the recent five-year period (2009-2014). This pattern was particularly discernible in two patches of Filipendulo ulmariae-Menthetum longifoliae, each exhibiting a different trend. In the case of patch 2, the low similarity level should be attributed primarily to the changes in the species

b
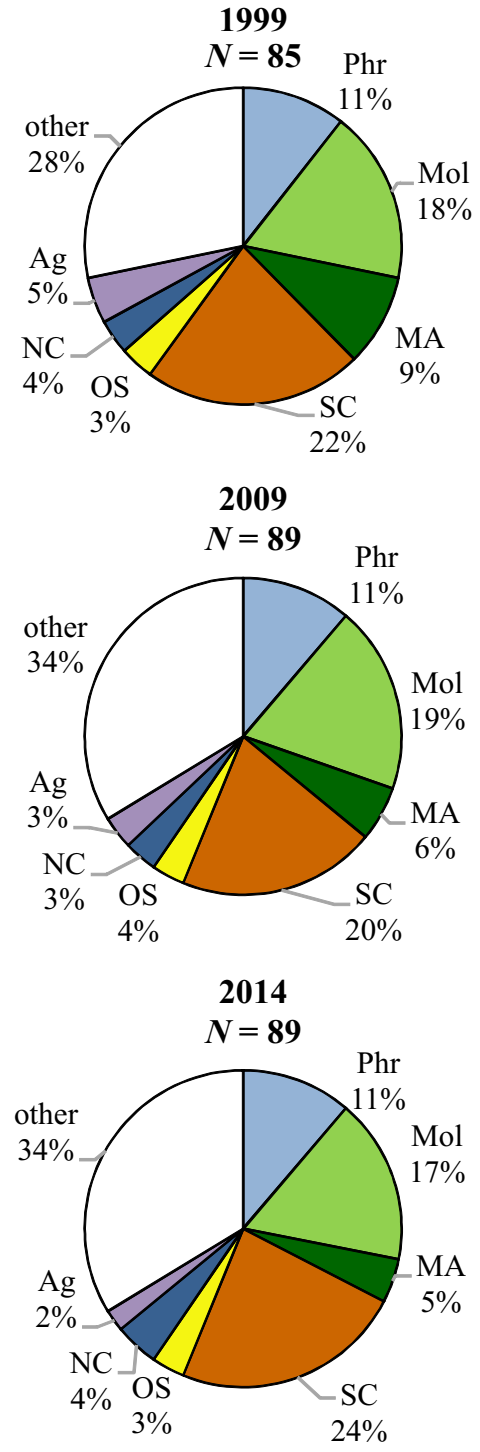

Fig. 2 Ecological differentiation of meadow (a) and peatbog (b) vegetation in the Szum River valley in the years 1999, 2009 and 2014: Phr - rush species of the class Phragmitetea; Mol - wet meadow species of the order Molinietalia caeruleae; MA - fresh meadow species of the class Molinio-Arrhenatheretea;SC - transitional peatbog species of the class Scheuchzerio-Caricetea nigrae; OS - raised peatbog species of the class Oxycocco-Sphagnetea; $\mathrm{NC}$ - poor grassland species of the class Nardo-Callunetea; Ag bog-alder forest species of the class Alnetea glutinosae. $N$ - number of species. 
composition, since the differences in species richness were not spectacular (22 and 18 taxa, respectively). The increase in the Carex acutiformis Ehrh. cover resulted in a decline in the share of meadow species, e.g. Angelica sylvestris L., C. oleraceum, Galium mollugo L., or Myosotis palustris (L.) L. em. Rchb. The low values of the Jaccard index in patch 3 (0.47) result from a significant increase in the number of taxa, which was not prevented by the massive encroachment of Phragmites australis (Cav.) Trin. ex Steud (Tab. 1, Tab. 3). A similarly low value of the Jaccard index (0.48) was noted in patch 5 where a noticeable decrease of species richness took place. The proportion of meadow species [Cirsium palustre (L.) Scop., C. rivulare, Filipendula ulmaria, and Lychnis floscuculi L.] decreased, whereas the rate of disappearance of rush and bog alder species was lower. The largest increase in the cover was exhibited by C. acutiformis, similarly to patch 2 .

The smallest quantitative and qualitative changes occurred in patches 1 and 6 which indicated the higher values of the Jaccard index (0.61 and 0.59, respectively). In patch 1 , despite the increase of species number species similarity was at a relatively high level $(0.61)$, which means that the majority of species identified in the first study period persisted in the patch for the next 15 years. Patch 6 is located $400 \mathrm{~m}$ down the river away from the other meadow patches (cf. Fig. 1b). Both the number of taxa and the relatively high and similar values of the diversity index throughout the study periods indicate high stability of the community (Tab. 1, Tab. 3).

In all the study periods, taxa characteristic of variablewetness meadows (the order Molinietalia - 32-38\%) dominated, followed by species of rush communities (13-16\%) and fresh meadow communities (6-15\%). The other distinguished classes were represented by less than $10 \%$ of all taxa each (Fig. 2a).

In the case of peatbog communities, the highest floristic similarity (0.68) was noted in patches 9 and 10 , which indicates the dominance of the core species in these communities. The most substantial floristic changes were found in the Sphagnetum magellanici raised bog - patches 13 and 14 , as indicated by the very low values of the Jaccard index, i.e. 0.31 and 0.44 , respectively. Simultaneously, the trend in the changes in the diversity index values differed between the two patches (Tab. 3).

Tab. 2 Changes in species richness and diversity of selected peatbog communities in the Szum River valley.

\begin{tabular}{|c|c|c|c|c|c|c|c|c|c|}
\hline \multirow[b]{2}{*}{ Patch No. } & \multirow{2}{*}{$\begin{array}{c}\text { Relevé } \\
\text { area }\left(\mathbf{m}^{2}\right)\end{array}$} & \multicolumn{2}{|c|}{ Community } & \multicolumn{3}{|c|}{ No. of vascular plants } & \multicolumn{3}{|c|}{ Shannon-Wiener index } \\
\hline & & 1999 & 2014 & 1999 & 2009 & 2014 & 1999 & 2009 & 2014 \\
\hline 7. & 120 & $\begin{array}{l}\text { Caricetum limosae Br.-Bl. } \\
1921\end{array}$ & $\begin{array}{l}\text { Caricetum limosae Br.-Bl. } \\
1921\end{array}$ & 24 & 29 & 26 & 1.23 & 1.37 & 1.35 \\
\hline 8. & 150 & \multirow{2}{*}{$\begin{array}{l}\text { Rhynchosporetum albae } \\
\text { Koch } 1926\end{array}$} & \multirow{2}{*}{$\begin{array}{l}\text { Rhynchosporetum albae } \\
\text { Koch } 1926\end{array}$} & 23 & 28 & 41 & 1.26 & 1.35 & 1.53 \\
\hline 9. & 150 & & & 26 & 32 & 26 & 1.34 & 1.42 & 1.29 \\
\hline 10. & 150 & \multirow{2}{*}{$\begin{array}{l}\text { Caricetum lasiocarpae } \\
\text { Koch } 1926\end{array}$} & \multirow{2}{*}{$\begin{array}{l}\text { Caricetum lasiocarpae } \\
\text { Koch } 1926\end{array}$} & 22 & 22 & 25 & 1.23 & 1.19 & 1.31 \\
\hline 11. & 150 & & & 36 & 37 & 29 & 1.47 & 1.44 & 1.30 \\
\hline 12. & 80 & $\begin{array}{l}\text { Caricetum davallianae } \\
\text { Dutoit } 1924 \text { em. Görs } 1963\end{array}$ & $\begin{array}{l}\text { Caricetum davallianae } \\
\text { Dutoit } 1924 \text { em. Görs } 1963\end{array}$ & 34 & 35 & 34 & 1.46 & 1.46 & 1.42 \\
\hline 13. & 150 & Sphagnetum magellanici & Sphagnetum magellanici & 19 & 35 & 27 & 1.18 & 1.44 & 1.34 \\
\hline 14. & 150 & $\begin{array}{l}\text { (Malc. 1929) Kästner at } \\
\text { Flössner } 1933\end{array}$ & $\begin{array}{l}\text { (Malc. 1929) Kästner at } \\
\text { Flössner } 1933\end{array}$ & 36 & 34 & 34 & 1.47 & 1.37 & 1.36 \\
\hline
\end{tabular}

Tab. 3 The Jaccard index for particular times of the study of selected meadow and peatbog communities in the Szum River valley.

\begin{tabular}{cccccccc}
\hline & & & & & \multicolumn{3}{c}{ Peatbog communities } \\
Patch & \multicolumn{2}{c}{ No. } & \multicolumn{1}{c}{$\mathbf{1 9 9 9 / 2 0 0 9}$} & $\mathbf{2 0 0 9 / 2 0 1 4}$ & $\mathbf{1 9 9 9 / 2 0 1 4}$ & $\begin{array}{c}\text { Patch } \\
\text { No. }\end{array}$ & \multicolumn{3}{c}{$\mathbf{1 9 9 9 / 2 0 0 9}$} & $\mathbf{2 0 0 9 / 2 0 1 4}$ & $\mathbf{1 9 9 9 / 2 0 1 4}$ \\
\hline 1. & 0.69 & 0.74 & 0.61 & 7. & 0.68 & 0.53 & 0.56 \\
2. & 0.31 & 0.68 & 0.52 & 8. & 0.51 & 0.37 & 0.53 \\
3. & 0.41 & 0.79 & 0.47 & 9. & 0.73 & 0.66 & 0.68 \\
4. & 0.52 & 0.69 & 0.55 & 10. & 0.53 & 0.62 & 0.68 \\
5. & 0.56 & 0.62 & 0.48 & 11. & 0.55 & 0.44 & 0.53 \\
6. & 0.61 & 0.64 & 0.59 & 12. & 0.59 & 0.62 & 0.55 \\
& - & - & - & 13. & 0.61 & 0.72 & 0.31 \\
& - & - & - & 14. & 0.52 & 0.49 & 0.44 \\
\hline
\end{tabular}


In 1999-2014, the total number of constituent species in the 8 analyzed peatbog patches and the share of the individual syntaxonomic groups varied insignificantly, i.e. in the range of $85-89$ (Fig. 2b), although changes in the cover of individual taxa were observed. Taxa of the class Scheuchzerio-caricetea nigrae exhibited the highest share (20-24\%) and were accompanied by species of variablewetness meadows (17-19\%) and rushes (11\% in all the study years). Species of raised peatbogs constituted barely 3-4\% of all floristic elements of the analyzed patches (Fig. 2b). In a majority of the patches, an increase in shrub cover [Alnus glutinosa (L.) Gaertn., Betula pendula Roth, Pinus sylvestris L., Salix cinerea L.] was found. In the peatbog sward, an increasing trend was exhibited by Carex rostrata Stokes, Cirsium palustre, Eupatorium cannabinum L., Lysimachia vulgaris, Mentha arvensis L., Potentilla erecta (L.) Hampe, Thelypteris palustris Schott, and locally Phragmites australis (e.g. patches 11 and 14) or Typha angustifolia L. (patch 10). Fluctuations were observed in the case of Carex panicea, Menyanthes trifoliata, and Viola palustris L., and a downward trend was evident in several species, including rare, protected and/or endangered ones, particularly in Carex limosa, C. oederi Retz., Drosera rotundifolia, D. intermedia, Dactylorhiza majalis, D. maculata, Epipactis palustris, and Scheuchzeria palustris. The share of Andromeda polifolia, Carex davalliana, C. lepidocarpa, Equisetum fluviatile L., Oxycoccus palustris, and Rhynchospora alba remained at a comparable level.

\section{Discussion}

The temporal changes of vegetation in the macroforb meadow habitat in the Szum River valley were caused by the construction of a large reservoir (5.88 ha) in Aleksandrów at a distance of approx. $3.5 \mathrm{~km}$ downstream of the study area at the beginning of the last decade. Beavers, which were disturbed during the construction of this structure, moved up the river (2005) where they built a small dam. At the beginning of the 2006 growing season, a rapid rise in the groundwater level was reported from the area. The high water level in the Cirsietum rivularis patch (No. 4) persisted for another two seasons. During that time, the entire Lysimachio vulgaris-Filipenduletum patch (illustrated by relevé No. 5) was waterlogged with $30 \mathrm{~cm}$ of stagnant water at the highest water levels. The beaver colony ceased to function after three seasons, since the animals disturbed by users of a nearby tourist route moved farther up the river [11]. Since the dam was not strengthened by the beavers, in the early spring of 2008 the waters from the catchment began to flow freely into the river and the water table was lowered and reached the level before the waterlogging.

The effects of the activity of the beavers, i.e. efficient "environmental engineers", are more pronounced at the landscape level (dams, small water reservoirs, elimination of shrubs and trees). In turn, the effect of their activity on biodiversity is ambiguous, since both an increase and a decrease in species and phytocoenotic diversity can be observed [15,29-31].
Fluctuations of the groundwater table and accompanying waterlogging, which induce changes in other habitat conditions, are important factors in the determination of individuals' traits and the characteristics of species populations of hydrogenic habitats. Within a short time, they can contribute to changes at the level of vegetation. The unstable hydrological conditions created by the presence of the beavers had an impact on the meadow phytocoenoses in the Szum River valley. The Lysimachio vulgaris-Filipenduletum meadow (patch 5) was transformed within a short time (2005-2008) into a poor Caricetum acutiformis sedge rush. In patch 4 , the most important characteristic species of the association, i.e. Cirsium rivulare, exhibited low tolerance to elevated water levels and significantly reduced the cover in favor of Lysimachia vulgaris. Currently, the patch has been described as a Lysimachio vulgaris-Filipenduletum association. In the analyzed meadow patches, the rapid increase in habitat wetness caused a decline in the species richness of vascular plants, a reduction in the value of the Shanno-Wiener index, and a reduced share of species characteristic of macroforb variable-moisture meadows. A similar relationship was observed in the Rawka River valley where the European beaver was reintroduced. The activity of the animals resulted in a rise in the groundwater level and an increased share of rush and aquatic vegetation [14].

A positive aspect of the beavers' presence was noted in the investigated section of the Szum River valley. Cutting willow shrubs and undergrowth as well as young alder, willow, and birch or even pine trees impedes succession on meadows and peatbogs for some time. This impact of the "environmental engineers" simulates one of the most common methods for active protection of valuable hydrogenic habitats, i.e. removal of trees and shrubs [32,33].

One of the main causes of wetland changes is the interference in the natural water cycle $[32,34]$ by building a system of drainage ditches (faulty drainage) and road or railway embankments, which can cause excessive drainage or irrigation of peatbog ecosystems, respectively. Such anthropogenic impacts prevailing at the beginning of the first and second halves of the 20th century led to degradation of the nearby "Międzyrzeki" peatbog located in the Roztocze National Park $[35,36]$. For the last two decades, the cause of peatbog degradation has been attributed to the so-called small-scale water retention structures constructed in private wetlands. A small pond (ca. 9000 square meters) constructed in the autumn of 2001 on the right-side bank of the Szum River valley is situated in a bog-spring habitat (Carici canescentis-Agrostietum caninae, Caricetum paniceo-lepidocarpae) with the presence of rare orchids Dactylorhiza majalis, D. fuchsii, and Epipactis palustris. The reservoir is recharged with hillside spring waters that are discharged through a narrow ditch directly into the pond, which contributes to peatbog drainage. Additionally, the neighboring willow-alder scrubs have been cut, which has led to rapid growth of offshoot willows and alders [11]. Another reflection of the degradation of valuable patches of the eutrophic bog-spring habitat on the left bank of the river (Caricetum davallianae, C. paniceo-lepidocarpae) with mass occurrence of Dactylorhiza majalis and D. maculata surrounded by grassland-sedge communities [e.g. Holcus 
lanatus L., Briza media L., Anthoxanthum odoratum L., Arrhenatherum elatius (L.) P. Beauv. ex J. Presl \& C. Presl, Carex gracilis Curtis, Juncus effusus L. and J. conglomeratus L. em. Leers] was alder plantings preceded by digging of shallow ditches at approx. 5-m intervals, which resulted in drainage of the area and homogenization and impoverishment of the vegetation. At present, the alder specimens reach a height of 5-8 $\mathrm{m}$ and groups of herbaceous species, sedges, and grasses with unidentified syntaxonomy grow between the rows.

Within the 15-year period, the Sphagnetum magellanici raised bog appeared to be least stable, although the causes varied between the analyzed patches. In patch 13 , the drastic decrease in floristic similarity was probably caused by the isolation of the patch surrounded mainly by rush and meadow communities. In turn, the reduction in diversity and floristic similarity in patch 14 is attributed to the massive growth of Phragmites australis and increased shrub layer

\section{Acknowledgments}

The authors are grateful to two anonymous reviewers for their valuable comments. We would like to thank Dr. Anna Rysiak for assistance in field work, and Mrs. Anna Wesołowska-Zoń for improving our English. Research was supported financially by the Department of Ecology, Institute of Biology and Biochemistry, Maria Curie-Skłodowska University.

\section{Authors' contributions}

The following declarations about authors' contributions to the research have been made: design of the study: BC, MF; field work: BC, MF; writing the manuscript: $\mathrm{BC}, \mathrm{MF}$.

\section{Competing interests}

No competing interests have been declared.

\section{References}

1. Tomiałojć L, editor. Ochrona przyrody i środowiska w dolinach nizinnych rzek Polski. Kraków: Wydawnictwo Instytutu Ochrony Przyrody; 1993.

2. Nawrocki P. Walory przyrodnicze dolin rzecznych. In: Mioduszewski W, editor. Woda w krajobrazie rolniczym; 2006. p. 80-88. (Woda środowisko - obszary wiejskie, rozprawy naukowe i monografie; vol 18).

3. Ward JV, Tockner K, Arscott DB, Claret C. Riverine landscape diversity. Freshw Biol. 2002;47(4):517-539. http://dx.doi. org/10.1046/j.1365-2427.2002.00893.x

4. de Nooij RJW, Verberk WCEP, Lenders HJR, Leuven RSEW, Nienhuis $\mathrm{PH}$. The importance of hydrodynamics for protected and endangered biodiversity of lowland rivers. Hydrobiologia. 2006;565(1):153-162. http://dx.doi.org/10.1007/s10750-005-1911-9

5. Czarnecka B, Pelc M. Biodiversity on the floristic and phytocoenotic levels: the comparison of forest and non-forest landscapes in small river valleys. Ecological Questions. 2007;8:37-45.

6. Warda M, Stamirowska-Krzaczek E, Kulik M. Floristic diversity of selected plant communities on extensive and abandoned grasslands in the Nadwieprzański Landscape Park. J Water Land Dev. 2013;19(7-12):77-82.

7. Czarnecka B, Janiec B. Przełomy rzeczne Roztocza jako modelowe obiekty w edukacji ekologicznej. Lublin: Wydawnictwo Uniwersytetu Marii Curie-Skłodowskiej; 2002.

8. Czarnecka B. Plant cover of the Szum River valley (Roztocze, southeast Poland). Acta Soc Bot Pol. 2005;74(1):43-51. http://dx.doi. org/10.5586/asbp.2005.008

9. Sikorski P, Wierzba M, Wysocki C, Pawlicki R. Długoterminowe cover, which worsens the light conditions near the ground. A similar trend in peatbog changes is observed regardless of the physico-geographical region [37-39].

Despite the multidirectional changes, the peatbogs near Górecko Kościelne have retained high phytocoenotic and species diversity, which indicates their highly natural character. In 8 relevés subjected to detailed analysis, 85-89 vascular plant species were found in the successive study periods. In comparison, Sotek et al. [37] recorded 95 vascular plant species in 8 midfield peatbogs with a total surface area of over 60 ha in Pomerania. In turn, Malec [40] found only 20 species in the 161-ha "Puścizna Długopole" peatbog in the Orawa-Nowy Targ Basin. In general, the riverine peatlands of the Central Roztocze and particularly the mires in the Szum River valley are characterized by greater floristic richness and diversity as expressed by the Shannon-Wiener index than the peatlands of another region of southern Poland, the Łęczna-Włodawa Lakeland [41].

zmiany roślinności w dolinie rzeki Blankowa - problemy w ocenie skuteczności jej ochrony. Probl Ekol Kraj. 2006;16:413-425.

10. Kaczmarek Z, Grzelak M, Gajewski P. Warunki siedliskowe oraz różnorodność florystyczna ekologicznych siedlisk przyrodniczych w dolinie Noteci. J Res Appl Agric Engin. 2010;55:142-146.

11. Czarnecka B. Wpływ zmiany stosunków wodnych na walory przyrodnicze i rekreacyjne małej doliny rzecznej. Probl Ekol Kraj. 2010;27:113-122.

12. Mioduszewski W. Small water reservoirs - their function and construction. J Water Land Dev. 2012;17(1-3):45-52.

13. Łaska G. Protection of floristic diversity in the Sajna River valley in view of the planned construction of hydroelectric power station in Sarkajmy. J Water Land Dev. 2014;20(1-3):45-56. http://dx.doi. org/10.2478/jwld-2014-0002

14. Kobojek E. Środowiskowe skutki reintrodukcji bobra (Castor fiber) w dolinie Rawki. Przegl Geogr. 2005;77:383-396.

15. Rosell F, Bozśer O, Collen P, Parker H. Ecological impact of beavers Castor fiber and Castor canadensis and their ability to modify ecosystems. Mamm Rev. 2005;35(3-4):248-276. http://dx.doi. org/10.1111/j.1365-2907.2005.00067.x

16. Franczak M, Czarnecka B. Przemiany zmiennowilgotnych łąk ziołoroślowych na poziomie fitocenotycznym i populacyjnym. Inż Ekol. 2012;29:38-47.

17. Czarnecka B, Janiec B. Abiotic conditions affecting the biodiversity of the "Szum" landscape reserve in Roztocze. Ekológia (Bratislava). 2001;20(4 suppl):207-214.

18. Krebs CJ. Ekologia. Eksperymentalna analiza rozmieszczenia i liczebności. Warszawa: Wydawnictwo Naukowe PWN; 2011.

19. Mirek Z, Piękoś-Mirkowa H, Zając A, Zając M, editors. Flowering plants and pteridophytes of Poland - a checklist. Kraków: W. Szafer Institute of Botany, Polish Academy of Sciences; 2002. (Biodiversity of Poland; vol 1).

20. Ochyra R, Żarnowiec J, Bednarek-Ochyra H. Census catalogue of Polish mosses. Kraków: W. Szafer Institute of Botany, Polish Academy of Sciences; 2003. (Biodiversity of Poland; vol 3).

21. Brzeg A, Wojterska M. Zespoły roślinne Wielkopolski, ich stan poznania i zagrożenie. In: Wojterska M, editor. Szata roślinna Wielkopolski i Pojezierza Południowopomorskiego. Przewodnik sesji terenowych 52. Zjazdu PTB, 24-28 września 2001. Poznań: Bogucki Wydawnictwo Naukowe; 2001. p. 33-110.

22. Matuszkiewicz W. Przewodnik do oznaczania zbiorowisk roślinnych Polski. Warszawa: Wydawnictwo Naukowe PWN; 2008.

23. Rozporządzenie Ministra Środowiska w sprawie gatunków dziko 
występujących roślin objętych ochroną, 5 stycznia 2012. Dz. U. 2022, poz. 81.

24. Kucharczyk M. Ginące i zagrożone gatunki roślin naczyniowych województwa lubelskiego [Manuscript]. Lublin: Lubelski Urząd Wojewódzki; 2000.

25. Kopeć D, Michalska-Hejduk D. How threatened is the Polish wetland flora? Oceanol Hydrobiol Stud. 2012;41(3):79-89. http://dx.doi. org/10.2478/s13545-012-0030-2

26. Rozporządzenie Ministra Środowiska z dnia 14 sierpnia 2001 r. w sprawie określenia rodzajów siedlisk przyrodniczych podlegających ochronie, Dz. U. 92 z dnia 3 września 2001, poz. 1029.

27. Habitats Directive (directive on the conservation of natural habitats and of wild fauna and flora, 92/43/EEC); 1992.

28. Herbich J, editor. Wody słodkie i torfowiska. Poradniki ochrony siedlisk i gatunków Natura 2000 - podręcznik metodyczny. Warszawa: Ministerstwo Środowiska; 2004. (vol 2).

29. Jones CG, Lawton JH, Shachak M. Positive and negative effects of organisms as physical ecosystem engineers. Ecology. 1997;78(7):19461957. http://dx.doi.org/10.2307/2265935

30. Wright JP, Jones CG, Flecker AS. An ecosystem engineer, the beaver, increases species richness at the landscape scale. Oecologia. 2002;132(1):96-101. http://dx.doi.org/10.1007/s00442-002-0929-1

31. Anderson CB, Rosemond AD. Ecosystem engineering by invasive exotic beavers reduces in-stream diversity and enhances ecosystem function in Cape Horn, Chile. Oecologia. 2007;154(1):141-153. http:// dx.doi.org/10.1007/s00442-007-0757-4

32. Pawlaczyk P, Wołejko L, Jermaczek A, Stańko R. Poradnik ochrony mokradeł. Świebodzin: Wydawnictwo Lubuskiego Klubu Przyrodników; 2001.

33. Schubert T. Usuwanie drzew i krzewów na torfowiskach - jedna z metod czynnej ochrony torfowisk. Stud Lim Tel. 2010;4(2):75-84.

34. Ilnicki P, editor. Torfowiska i torf. Poznań: Wydawnictwo Akademii Rolniczej im. Augusta Cieszkowskiego w Poznaniu; 2002.

35. Izdebski K, Czarnecka B, Grądziel T, Lorens B, Popiołek Z. Zbiorowiska roślinne Roztoczańskiego Parku Narodowego na tle warunków siedliskowych. Lublin: Wydawnictwo Uniwersytetu Marii CurieSkłodowskiej; 1992.

36. Bartoszewski S, Lorens B. Wybrane problemy renaturalizacji torfowisk w rejonie Bagna Międzyrzeki (RPN). In: Radwan S, Kornijów R, editors. Problemy aktywnej ochrony ekosystemów wodnych i torfowiskowych w polskich parkach narodowych. Materiały międzynarodowej konferencji. Okuninka n/Jeziorem Białym Włodawskim, 8-9.X.1999. Lublin: Akademia Rolnicza; 1999. p. 101-108.

37. Sotek Z, Stasińska M, Prajs B, Gamrat R, Łysko A. Torfowiska śródpolne województwa zachodniopomorskiego. Woda - Środowisko - Obszary Wiejskie. 2004;4(2b):211-224.

38. Proćków J, Szczęśniak E. Zbiorowiska roślinne rezerwatu “Torfowisko
Kunickie" koło Legnicy - ocena dynamiki i zagrożeń. Acta Bot Sil. 2009;4:43-90.

39. Michalska-Hejduk D, Kopeć D. Szata roślinna torfowiska Żabieniec - stan obecny i dynamika. In: Twardy J, Żurek S, Forysiak J, editors. Torfowisko Żabieniec - warunki naturalne, rozwój i zapis zmian paleoekologicznych w jego osadach. Poznań: Bogucki Wydawnictwo Naukowe; 2010. p. 75-88.

40. Malec M. Stan aktualny i antropogeniczne przekształcenia ekosystemu torfowiska Puścizna Długopole w Kotlinie Orawsko-Nowotarskiej. Ochr Środ Zasob Nat. 2011;49(11):548-558.

41. Sugier P, Czarnecka B. Factors affecting the diversity of vegetation of chosen lakeland and riverine peatlands (SE Poland). Annales UMCS C. 2012;67(1):57-66.

\section{Przemiany zbiorowisk łąkowych i torfowiskowych w krajobrazie małej doliny rzecznej Roztocza Środkowego}

\section{Streszczenie}

Szum, rzeka IV rzędu, jest prawobrzeżnym dopływem Tanwi, przecinającym strefę południowej krawędzi Roztocza Środkowego (SE Polska). Poniżej ścisłego przełomu rzeki, na odcinku między 10. a 12. kilometrem biegu rzeki, w dolinie Szumu wykształciły się kompleksy łąkowo-torfowiskowe związane z glebami semihydrogenicznymi i bagiennymi o zróżnicowanej trofii, od siedlisk oligo- po eutroficzne. Na powierzchni ok. 13 hektarów najcenniejszych siedlisk nieleśnych zidentyfikowano szereg zbiorowisk roślinnych, wśród których są siedliska sieci Natura 2000 oraz podlegające ochronie na mocy Rozporządzenia Ministra Środowiska z 2001 roku. Są to m.in. zespoły łąkowe: Lysimachio vulgaris-Filipenduletum, Lythro-Filipenduletum, Filipendulo ulmariae-Menthetum longifoliae, Angelico-Cirsietum oleracei, Cirsietum rivularis. Wśród zbiorowisk mszysto-turzycowych i mszarów na uwagę zasługują zespoły: Caricetum limosae, Rhynchosporetum albae, Caricetum lasiocarpae, Caricetum paniceo-lepidocarpae, Caricetum davallianae i Sphagnetum magellanici. Zbiorowiska te buduje ok. 160 gatunków roślin naczyniowych i 40 gatunków mchów i wątrobowców. W latach 1999-2014 największe zmiany nastąpiły w obrębie łąk ziołoroślowych: niewielkie płaty Angelico-Cirsietum oleracei i Cirsietum rivularis przekształciły się w Lysimachio vulgaris-Filipenduletum, a część płatów tego ostatniego zespołu przekształciła się w szuwar Caricetum acutiformis. Zniszczonych zostało bezpowrotnie kilka płatów młak Caricetum paniceo-lepidocarpae i Carici canescentis-Agrostietum caninae. Wśród zachowanych torfowisk najmniej stabilnym okazało się zbiorowisko Sphagnetum magellanici. Obserwowane w ciągu ostatnich 15 lat przemiany roślinności łąk i torfowisk są wynikiem naturalnych procesów zachodzących w dolinie rzecznej, ale w znacznym stopniu również działań człowieka w zakresie tzw. małej retencji oraz bytowania, a następnie wycofania się kolonii bobrów. Pomimo różnokierunkowych przemian, torfowiska w dolinie Szumu ciągle jeszcze zachowują wysoką różnorodność fitocenotyczną i gatunkową, co świadczy o znacznym stopniu ich naturalności. 